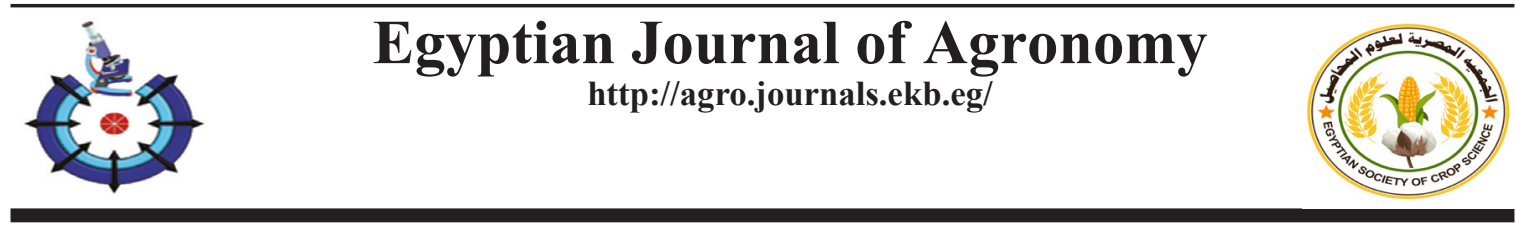

\title{
Estimation of Combining Ability and Heterosis for Wheat Yield and Its Components under Water Stress Conditions
}

\author{
Marwa M. El-Nahas", Osama A.M. Ali \\ Crop Science Department, Faculty of Agriculture, Menoufia University, Menoufia, \\ Egypt.
}

\begin{abstract}
D ROUGHT is a worldwide problem which controls the crop productivity. Six Egyptian bread wheat varieties were crossed in a $6 \times 6$ half diallel in 2018/19 season. Parents and their fifteen $\mathrm{F} 1$ crosses were evaluated under normal irrigation (N), mid water stress (MS) and severe water stress (SS) during 2019/20 in three field experiments. Results showed that the analysis of variance were significant for all the studied traits. The highest mean values were recorded under all irrigation treatments as well as the combined analysis with the crosses P1x P2, P1 x P3, P1 x P5, P2 x P3, P3 x P5 and P5 x P6 for grain yield per plant. Mean squares for both general (GCA) and specific (SCA) combining ability estimates were highly significant for all studied traits. GCA/SCA ratio was greater than unity for most traits. The parental P1 exhibited positive and significant GCA effects for number of kernels per spike, grain yield per spike and grain yield per plant. The highest desirable SCA effects were obtained with the crosses P3 x P5 and $\mathrm{P} 4 \mathrm{x}$ P5 for grain yield per plant under stresses conditions. Positive significant heterosis were detected by the crosses P1 x P3, P2 x P3, P 3 x P5, P4 x P5 and P 5 x P6 for number of spikes per plant, number of kernels per spike, grain yield per spike, 1000-grain weight and grain yield per plant at N, MS, SS conditions and the combined data.
\end{abstract}

Keywords: Bread wheat, Diallel cross, Drought stress, General and Specific combining ability, Heterosis.

\section{Introduction}

Wheat is the most important cereal crop in the world. In Egypt, it is the main winter cereal crop which is being used as a stable food grain for urban and rural societies and as a major source of straw for animal feeding. The wheat area over the last years (2019-2000) has been expanded from 2.460 to 3.400 million fed (FAO, 2019). However, total wheat consumption has increased drastically due to overall population growth of about $2.5 \%$ per year. Therefore, Egypt imports about $45 \%$ of wheat requirements. This reflects the size of the problem and the efforts needed to increase the wheat production. Thus, increasing productivity of wheat, genotypes appears to be one of the important factors for narrowing the wheat production gap, due to extremely limited lands. This can be achieved by planting high potential yield varieties as well as conducted the best agricultural practices.

Water scarcity issues especially under climatic changes caused many problems to irrigated land in arid and semi-arid regions (Ding et al., 2021). Egypt presents a typical example of the drought problem faced in some arid districts (Hammad \& Ali, 2014). Irrigation is one of the most important factors in affecting crop productivity as well as water and fertilization use efficiency (Mehanna et al., 2013; Ali \& Mohammed, 2015). In Egypt, limited water resources are the main factor facing expansion of wheat growing areas. This position is will worsen due to creation of

"Corresponding author email: marwa_elnahas2010@yahoo.com

Received 29/6/2021; Accepted 01/9/2021

DOI: 10.21608 /agro.2021.77971.1268

C2021 National Information and Documentation Center (NIDOC) 
the Ethiopian water dam, which will affect the area of agricultural soil and cultivated plant genotypes (Abd El All \& Ali, 2019) Exposing plants to water stress adversely affects the plant growth and physiological efficiency (Hammad \& Ali, 2014), uptake and translocation of nutrients and hormonal balance (Gontia-Mishra et al., 2016) and productivity (Abd El All \& Ali, 2019; Ding et al., 2020).

Diallel cross technique was reported to provide early information on the genetic behavior in the first generation (Chowdhry et al., 1992). To establish any breeding program aimed at achieving high yield, breeders must have information on the nature of combining ability of parents, their behavior and hybrid combinations performance (Chawla \& Gupta, 1984). Combining ability analysis of Griffing (1956) is most widely used as biometrical tool for determining parental lines from where their ability to combine in hybrids. In this method, genetic variation is divided into general combining ability variance, a measure of additive gene action and specific combining ability variance, as a measure of dominance one. El-Hosary et al. (2012), Khaled \& Abd El-Daym (2014), Saeed et al. (2016), El-Saadoown et al. (2017), Qabil (2017), Mwadzingeni et al. (2018) and Khokhar et al. (2019) found that additive and non-additive gene effects were of great importance in controlling the genetic system of grain yield and its components.
Heterosis in wheat crosses for yield and its components were studied by Noorka et al. (2013), Gomaa et al. (2014), Ahmad et al. (2016), Thomas et al. (2017), Farhat \& Mohamed (2018) and Kumar et al. (2020). They found that the values of heterosis over the mid and better parents varied from positive to negative and from significant to insignificant for yield traits. The main objectives of the present study were: 1) Evaluate six wheat varieties under different water regimes. 2) Evaluate heterosis expression for grain yield and its components. 3) Estimate the magnitude of both general and specific combining abilities and their combined analysis under different treatments irrigation.

\section{Materials and Methods}

\section{Experimental procedures}

This investigation was carried out at the Experimental Farm, Faculty of Agriculture, Menoufia University, Shebin El-Kom, Egypt (latitude $30^{\circ} 31^{\prime} 39^{\prime \prime} \mathrm{N}$, longitude $31^{\circ} 04^{\prime} 03^{\prime} \mathrm{E}$ ) during the two growing successive seasons of 2018/19 and 2019/20. The properties of experimental soil at $30 \mathrm{~cm}$ were clay loam with $\mathrm{pH}$ of 7.6 , EC of $0.45 \mathrm{dSm}^{-1}$, organic matter content $1.8 \%$, permanent wilting point $18.2 \%$ and field capacity $38.6 \%$. Six Egyptian varieties of spring wheat representing a wide range of diversity for several agronomic traits and drought tolerance measurements were selected for this study. The names, pedigree and origin of these varieties are presented in Table 1.

TABLE 1. The code number, name, pedigree and origin of the studied parental varieties

\begin{tabular}{|c|c|c|c|}
\hline $\begin{array}{l}\text { Code } \\
\text { No. }\end{array}$ & Name & Pedigree & Origin \\
\hline 1 & Giza- 171 & $\begin{array}{c}\text { Sakha 93/ Gemmeiza } 9 \\
\text { Gz 2003-101-1Gz- 4Gz-1Gz-2Gz-0Gz }\end{array}$ & Egypt \\
\hline 2 & Misr-1 & $\begin{array}{c}\text { OASIS/SKAUZ//4*BCN/3/2*PASTOR. } \\
\text { CMSS00Y01881T-050M-030Y-030M-030WGY-33M-0Y--0EGY }\end{array}$ & Egypt \\
\hline 3 & Gemmeiza-12 & $\begin{array}{c}\text { OTUS/3/SARA/THB//VEE } \\
\text { CMSS97Y00227S-5y-010M-010Y-010M-2Y-1M-0Y-OGM }\end{array}$ & Egypt \\
\hline 4 & Shandawel-1 & $\begin{array}{l}\text { SITE//MO/4/NAC/TH.AC//3*PVN/3/MIRLO/BUC. } \\
\text { CMSS93B00567S-72Y-010M-010Y-010M-0HTY-0SH. }\end{array}$ & Egypt \\
\hline 5 & Sids-13 & ALMAZ.19=KAUZ”S"// TSI/ SNB"S" & Egypt \\
\hline 6 & Sakha-95 & $\begin{array}{c}\text { PASTOR//SITE/MO/3/CHEN/AEGILOPS SQUARROSA(TAUS)// } \\
\text { BCN/4/WBLL1 (CMSA01Y00158S-040P0Y-040M-030ZTM- } \\
\text { 040SY-26M-0Y-0SY-0S). }\end{array}$ & Egypt \\
\hline
\end{tabular}

Egypt. J. Agron. 43, No. 2 (2021) 
In 2018/19 season, the parents were crossed in a $6 \times 6$ diallel cross excluding reciprocals to produce fifteen hybrids. In 2019/20 season, three experiments using randomized complete block design with three replications were carried out on $14^{\text {th }}$ November 2019. Each experiment contained the six parents and their resulting $15 \mathrm{~F} 1$ 's. The first experiment was normally irrigation $(\mathrm{N})$ with $100 \%$ of $\mathrm{ET}_{\mathrm{c}}\left(1400 \mathrm{~m}^{3} / \mathrm{fed}\right)$, the second experiment (mid stress MS) with $80 \%$ of $\mathrm{ET}_{\mathrm{c}}\left(1120 \mathrm{~m}^{3} / \mathrm{fed}\right)$ and the third experiment (severe stress SS) with $60 \%$ of ET $\left(840 \mathrm{~m}^{3} / \mathrm{fed}\right)$. The three experiments were irrigated five times at 25, 55, 80, 105 and 125 days from sowing. The quantity of irrigation water was added according to the daily reference evapotranspiration $\left(\mathrm{ET}_{\mathrm{o}}\right)$ that obtained from the Central Laboratory of Agricultural Climate (CLAC) for Shebin El-Kom location using the Modified Penman-Monteith equation (Allen et al., 1998).

$\mathrm{ET}_{\mathrm{c}}=\mathrm{ET}_{\mathrm{o}} \times \mathrm{K}_{\mathrm{c}}$

where; ET: Crop evapotranspiration (mm/day); $\mathrm{ET}_{\mathrm{o}}$ : Reference evapotranspiration ( $\mathrm{mm} /$ day); $\mathrm{K}_{\mathrm{c}}$ : Crop coefficient during plant growth stages.

A suppressed rectangular weir was installed in the front the irrigation channels every irrigation to computed the amount of applied water to three irrigation system saccording to the following equation:

$\mathrm{Q}=1.84 \mathrm{~B} \mathrm{H}^{3 / 2}$

where; Q: Water flow rate $\left(\mathrm{m}^{3} / \mathrm{sec}\right)$; B: Length of weir or channel width(m); H: Head over the weir (m).

The amounts of total rainfall, temperature and crop coefficient during the evaluating season (2019/2020) at Shebin El-Kom were recorded in Table 2.

Each plot comprised single row three meters long with $30 \mathrm{~cm}$ between rows and $20 \mathrm{~cm}$ between plants. The proper culture practices were applied as recommended from Agriculture ministry for wheat production in all experiments.

\section{Measurements}

Ten competitive plants were taken randomly for the parental genotypes and their F1's from each plot for recording observations on different traits, i.e. plant height $(\mathrm{cm})$, number of spikes per plant, number of kernels per spike, grain yield per spike (g), 1000- grain weight (g) and grain yield per plant (g).

Statistical procedures:

Analysis of variance was conducted as outlined by Steel \& Torrie (1980) for all traits. The analysis of variance for combining ability and estimation of genetic of effects was done following the technique of Grifing (1956) method II model I for each experiment. The combined analysis of three experiments was carried out whenever homogeneity of error variance was detected by Gomez \& Gomez (1984). Mean data were used to estimate heterosis relative to mid parents according to Fonsecca \& Patterson (1968).

\section{Results and Discussion}

\section{Analysis of variance}

Analysis of variance for yield and its components under two water stresses, normal irrigation and combined analysis across the different environments are presented in Table 3. Mean squares due to irrigation treatments were highly significant for all studied traits, indicating overall differences between the three environments of study.

The mean squares due to genotypes were highly significant for all studied traits indicating, wide diversity among all genotypes used in this study. Moreover, significant mean squares among genotypes and treatments irrigation interaction were detected for all traits indicating, genotype responded differently to different treatments irrigation for these traits. Similar results were obtained by Gomaa et al. (2014), El-Saadoown et al. (2017), Khokhar et al. (2019) and Kumar et al. (2020).

TABLE 2. Monthly total rainfall and average temperature and Ke of wheat during 2019/2020 season

\begin{tabular}{|c|c|c|c|c|c|c|}
\hline $\begin{array}{ll}\text { Properties } & \text { Month } \\
\end{array}$ & $\begin{array}{l}\text { Nov. } \\
2019\end{array}$ & $\begin{array}{l}\text { Dec. } \\
2019\end{array}$ & $\begin{array}{l}\text { Jan. } \\
2020\end{array}$ & $\begin{array}{l}\text { Feb. } \\
2020\end{array}$ & $\begin{array}{l}\text { Mar. } \\
2020\end{array}$ & $\begin{array}{l}\text { Apr. } \\
2020\end{array}$ \\
\hline Max temperature $\left(\mathrm{C}^{\circ}\right)$ & 26.71 & 20.34 & 19.76 & 21.46 & 26.71 & 29.77 \\
\hline Min. temperature $\left(\mathrm{C}^{\circ}\right)$ & 17.92 & 13.02 & 11.27 & 12.39 & 16.74 & 18.77 \\
\hline Rainfall (mm/month) & - & - & 0.5 & 6.3 & 2.3 & 2.3 \\
\hline Kc & 0.65 & 0.60 & 0.50 & 0.70 & 0.75 & 0.70 \\
\hline
\end{tabular}




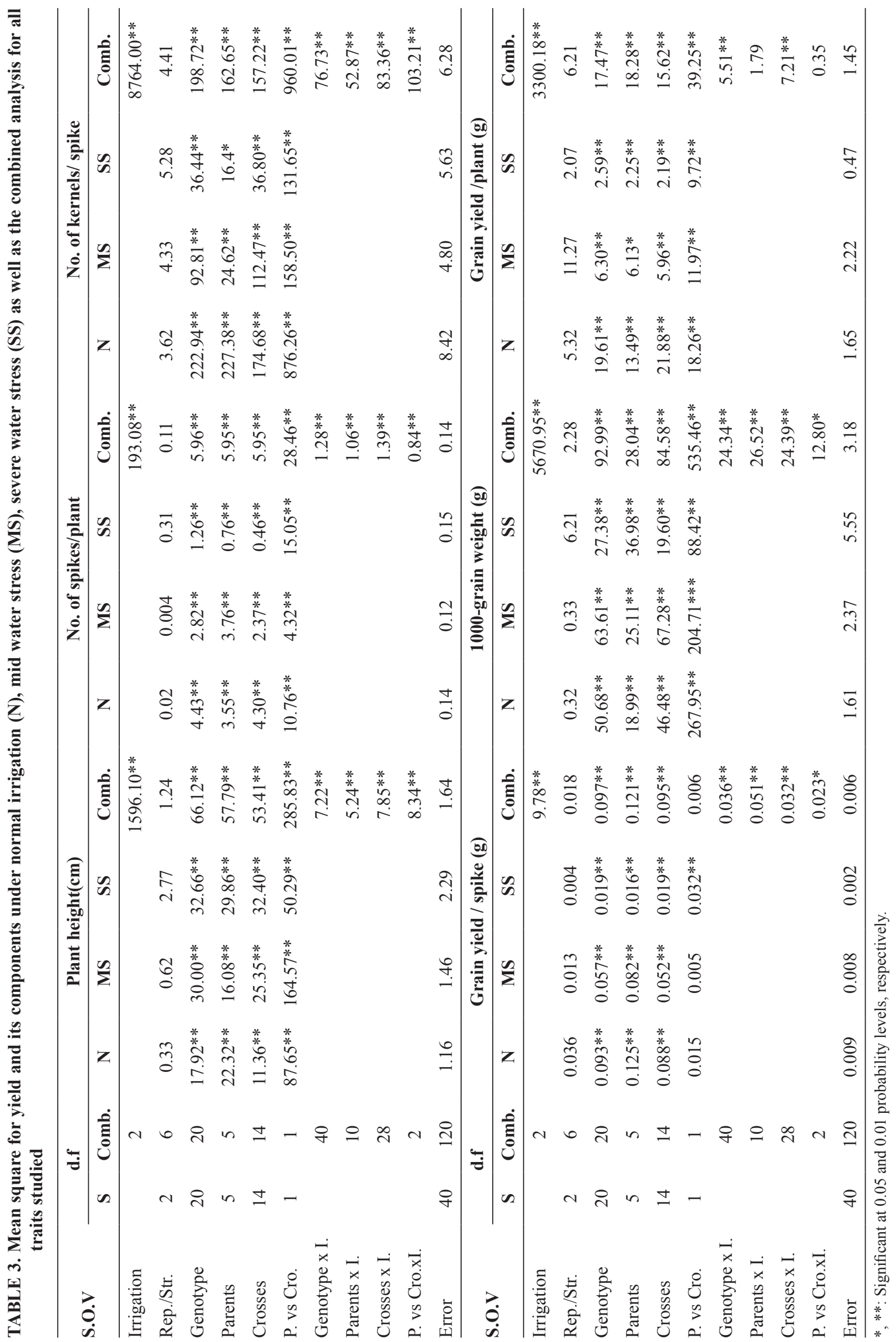

Egypt. J. Agron. 43, №. 2 (2021) 
Mean squares due to parents and crosses were highly significant for all traits in drought stress, normal irrigation and combined across them, indicating that these parents are different in their performance for all traits. Moreover, mean squares due to the interaction of irrigation treatments and both parents and crosses were significant for all traits, except for grain yield per plant in parents $\mathrm{x}$ irrigation. This result indicated that wheat parents responded differently to stress and non-stress conditions for these traits. Parents vs. crosses mean square was highly significant for all traits except, grain yield per spike under normal irrigation, mid water stress and combined analysis. Meanwhile, parents vs. crosses $\mathrm{x}$ irrigation treatment was significant for all traits except, grain yield per plant. These results are in the same trend with those of Khaled \& Abd El-Daym (2014), Qabil (2017) and Farhat \& Mohamed (2018).

\section{Mean performance}

Mean performance of the studied traits for parental wheat varieties and their F1 crosses at normal, stresses irrigation treatments as well as the combined analysis are shown in Table 4. Generally, under normal irrigation (favorable) the studied traits showed an increase when compared with drought stress. This result may be due to that drought stress restricted the production of wheat grain yield and contributing traits. In this connection, similar results were recorded by Khamssi (2012), Swelam et al. (2014) and Qabil (2017). Results cleared that the parental P5 gave the lowest mean value for plant height. Also, the crosses P1x P5 and P3 x P5 were the lowest mean value between crosses under this study.

The highest parents mean value for number of spikes per plant were recorded with the parent P2 and P5 followed by P1 then P6. However, seven crosses (P1 x P2, P1 x P5, P1 x P6, P2 x P3, P2 x P6, P3 x P5 and P5 x P6) exhibited highest mean values at normal, stress irrigation treatments as well as the combined analysis. For number of kernels per spike, the parents (P1 and $\mathrm{P} 2)$ and the crosses (P1 x P2, P1 x P3, P1 x P6, P2 x P3, P4 x P5 and $\mathrm{P} 5 \times \mathrm{P} 6$ ) give the highest mean values at normal, stress irrigation treatments as well as the combined analysis. For grain yield per spike, the parental varieties $\mathrm{P} 1$ and $\mathrm{P} 6$ recorded the greatest values. The crosses P1 x P2, P1 x P3, P4 x P5 had the highest mean values at all irrigation treatments as well as the combined analysis. The parental wheat variety P2 expressed the highest mean values of 1000-grain weight at all irrigation treatments and the combined data. Also, the crosses P1 x P2, P1 x P5, P2 x P4 and P3 $x$ P5 recorded the highest mean values under this investigation. For grain yield per plant, the parental wheat varieties $\mathrm{P} 1$ and $\mathrm{P} 2$ recorded the highest mean values. Also, the greatest mean values were recorded by the crosses P1 x P2, P1 x P3, P1 x P5, P2 x P3, P2 $\times \mathrm{P} 4, \mathrm{P} 3 \times \mathrm{P} 5$ and $\mathrm{P} 5$ x $\mathrm{P} 6$ at normal irrigation, stress water treatments as well as the combined analysis.

\section{Combining ability}

The analysis of variance for irrigation treatments (N, MS, SS) with the combined data for all traits studied are previously mentioned in Table 5 . General combining ability (GCA) and specific combining ability (SCA) mean squares were highly significant for all traits studied for both water stresses, normal irrigation and the combined data. These results indicated that both types of combining ability are important in the inheritance of these traits. The mean squares of the interactions between GCA, SCA and irrigation treatments were highly significant for all traits studied. This would indicate the importance of both additive and non-additive genetic variance in determining the performance of these traits.

GCA/SCA ratio was greater than unity for most traits under all treatments, indicating the major role of additive and additive $\mathrm{x}$ additive type of gene actions in the inheritance of these traits. While, GCA/SCA ratio was near to unity for number of spikes per plant under SS, grain yield per spike under all conditions, number of spikes per plant under N, MS and combined analysis and grain yield per plant under MS, revealing complete dominance of non-additive gene action in the inheritance of such traits. Similar results were previously obtained by Gomaa et al. (2014), El-Saadoown et al. (2017), Mwadzingeni et al. (2018) and Farhat \& Mohamed (2018).

\section{General combining ability effects (GCA)}

General combining ability effects (GCA) of each parent for all studied traits at normal irrigation $(\mathrm{N})$, mid water stress (MS), sever water stress (SS) as well as the combined analysis are presented in Table 6. The parental variety Giza-171 (P1) expressed significant desirable GCA effects for all studied traits in this investigation except, number of spikes per plant in SS and the combined analysis, 1000 -grain weight in $\mathrm{N}$ and $\mathrm{SS}$ and grain yield per plant in MS. The parental variety Misr-1 (P2) showed significant desirable for number of spikes per plant and 1000-grain weight in N, SS as well 
as the combined analysis, number of kernels per spike in $\mathrm{N}$, grain yield per spike in MS and grain yield per plant in N, MS and the combined analysis. The parental variety Gemmeiza-12 (P3) showed significant desirable GCA effects for plant height (towards shortness) in N and SS. The parental variety Shandawel-1 (P4) showed significant positive GCA effects for grain yield per spike in $\mathrm{N}$, MS, SS and the combined analysis. The parental variety Sids-13 (P5) expressed significant desirable for plant height (toward shortness) in N, MS, SS as well as the combined data. It showed significant positive GCA effects for number of spikes per plant in N, MS, SS and the combined analysis, number of kernels per spike in SS, grain yield per spike in MS and 1000-grain weight in N, SS and the combined analysis. The parental variety Sakha-95 (P6) showed significant positive GCA effects for number of spikes per plant in SS and the combined data. These results were in harmony with those obtained by El-Hosary et al. (2012), Khaled \& Abd El-Dayem (2014), Qabil (2017) and Farhat \& Mohamed (2018).

\section{Specific combining ability effects (SCA)}

Specific combining ability effects (SCA) for the F1 crosses for all studied traits at normal $(\mathrm{N})$, stresses irrigation (MS and SS) as well as the combined analysis are presented in Table 7. Regarding SCA effects for plant height, negative and significant SCA effects were obtained from the cross combinations ( $\mathrm{P} 2 \times \mathrm{P} 6)$ under normal irrigation condition and the cross (P3 x P5) under MS only. Significant positive SCA effects were attained by the cross combinations $(\mathrm{P} 1 \times \mathrm{P} 4, \mathrm{P} 2 \times \mathrm{P} 3$ and $\mathrm{P} 4$ $\mathrm{x}$ P5) under normal, stresses irrigation treatments as well as the combined analysis. Whereas, ten crosses were significant effects under normal irrigation for number of spike per plant. Positive significant SCA effects for number of kernels per spike content (Table7) in the crosses combinations (P1 x P3, P1 x P4, P2 x P5, P2 x P6 and P3 x P5) under normal irrigation treatments conditions, (P1 $\mathrm{x}$ P2, P2 x P3and P5 x P6) under stresses irrigation treatments and the combined analysis and the cross P4 x P5 under all irrigation treatments as well as the combined analysis. Regarding SCA effects for grain yield per spike, positive significant effect under normal, stresses irrigation treatments and the combined analysis was detected by the cross $\mathrm{P} 1 \mathrm{x}$ P3. Also, two crosses under N, four crosses under MS and four crosses under SS and the combined analysis. Estimation of SCA effects for 1000-grain weight, revealed positive and significant SCA effects for the three crosses (P1 x P2, P3 x P5 and
P4 x P6) under all irrigation treatments as well as the combined analysis. Three crosses (P1 x P5, P2 x P3 and P2 $\times$ P4) under N, SS and the combined data and the cross P5 x P6 under N, MS and the combined data. For grain yield per plant, estimates of SCA effects (Table7) were positive and significant for the crosses (P1 x P3, P2 x P3, P2 x P6 and P5 x P6) under normal irrigation, the crosses ( $\mathrm{P} 1 \times \mathrm{P} 3, \mathrm{P} 2 \times \mathrm{P} 3, \mathrm{P} 2$ $x$ P5, P4 x P5 and P5 x P6) under MS, the crosses (P3 $x$ P5 and P4 $x$ P5) under SS and the crosses (P1 $x$ P3, P3 x P5 and P4 x P5) under the combined data. Significant desirable SCA values for most of the studied traits were also reported by Ahmad et al. (2016), Saeed et al. (2016), Qabil (2017) Thomas et al. (2017), Farhat \& Mohamed (2018) and Khokhar et al. (2019).

\section{Heterosis}

Standard percent heterosis expressed by F1 hybrids over the mid parent for all studied traits at normal irrigation $(\mathrm{N})$, mid water stress (MS), severe water stress (SS) and their combined data are presented in Table 8. Negative heterosis for plant height was detected by the crosses P 2 x P5 and P $3 x$ $\mathrm{P} 5$ under MS. For number of spikes per plant, seven crosses showed highly significant heterosis relative to mid parent in all irrigation treatments under study and the combined data. Highly significant heterosis relative to mid parent was shown in number of kernels per spike at the crosses P1 x P2, P1 x P3, P2 x P3, P3 x P5, P4 x P5 and P5 x P6 at normal, stresses irrigation treatments and the combined data. For grain yield per spike, highly significant heterosis was detected in the crosses $\mathrm{P} 2 \times \mathrm{P} 3, \mathrm{P} 4 \times \mathrm{P} 5$ and $\mathrm{P} 5 \times \mathrm{P} 6$ at $\mathrm{N}$, the crosses $\mathrm{P} 1 \times \mathrm{P} 3, \mathrm{P} 2 \times \mathrm{P} 3$ and $\mathrm{P} 2$ $\mathrm{x}$ P5 at MS, the crosses P1 x P3, P2 x P4, P2 x P5, $\mathrm{P} 3 \times \mathrm{P} 5, \mathrm{P} 5 \times \mathrm{P} 6$ and $\mathrm{P} 4 \times \mathrm{P} 5$ at $\mathrm{SS}$ and the crosses P1 x P3, P2 x P3, P2 x P4, P2 x P5, P3 x P5, P4 $\mathrm{x}$ P5 and P5 x P6 at the combined analysis. Seven crosses were highly significant heterosis at normal, stresses irrigation treatments and the combined data for 1000-grain weight. Highly significant heterosis was detected for grain yield per plant in the crosses $\mathrm{P} 1 \times \mathrm{P} 3, \mathrm{P} 2 \times \mathrm{P} 3, \mathrm{P} 2 \times \mathrm{P} 6$ and $\mathrm{P} 3 \times \mathrm{P} 5$ at N, SS and the combined analysis, the cross $\mathrm{P} 2 \times \mathrm{P} 5$ at MS, the crosses $\mathrm{P} 1 \times \mathrm{P} 6, \mathrm{P} 2 \times \mathrm{P} 4$ and $\mathrm{P} 3 \times \mathrm{P} 6$ at SS, the cross $\mathrm{P} 4 \times \mathrm{P} 5$ at MS, SS and the combined analysis, the cross P4 x P6 at MS and the cross P5 x P6 at $\mathrm{N}, \mathrm{MS}, \mathrm{SS}$ and the combined data. A lot of workers reported the presence of considerable heterosis in wheat crosses for most traits, Noorka et al. (2013), Gomaa et al. (2014), Saeed et al. (2016), Thomas et al. (2017), Farhat \& Mohamed (2018) and Bhumika et al. (2018). 


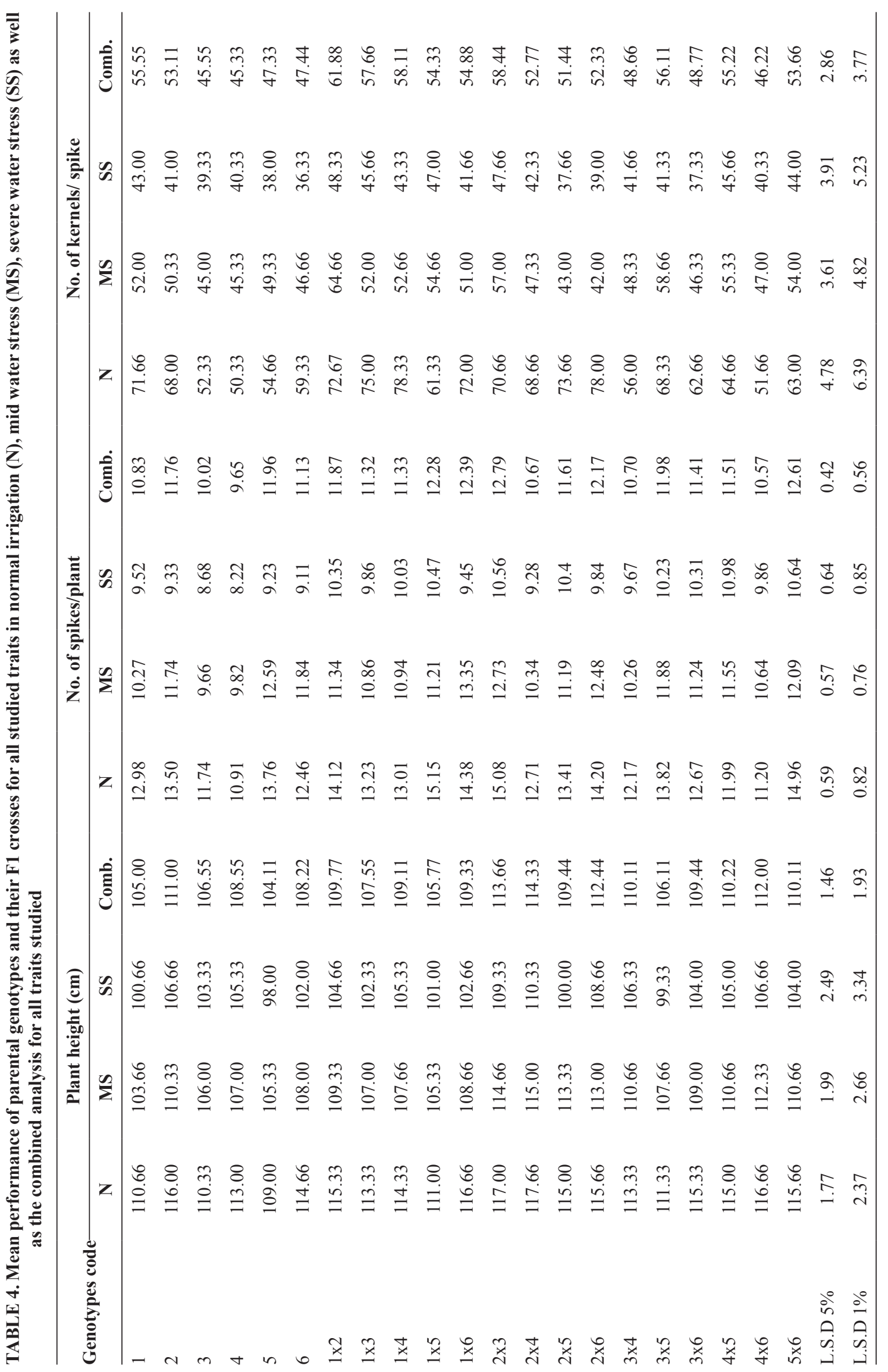

Egypt. J. Agron. 43, No. 2 (2021) 


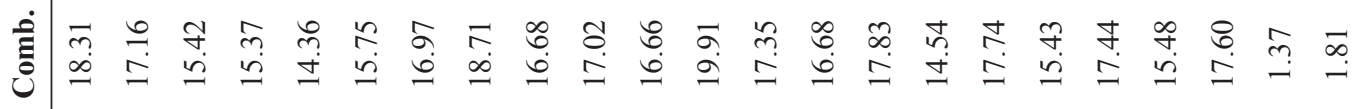

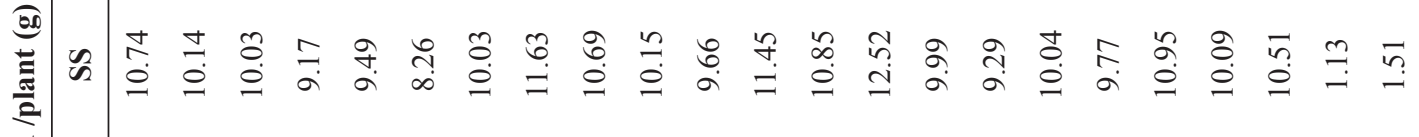

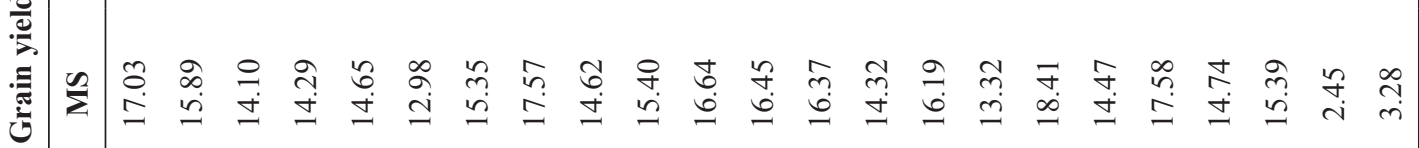

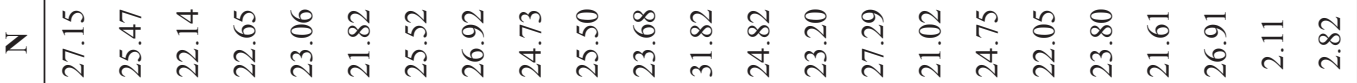

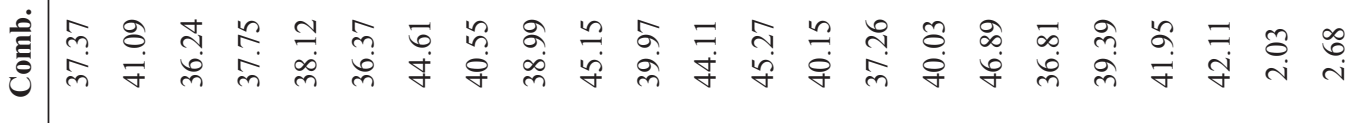

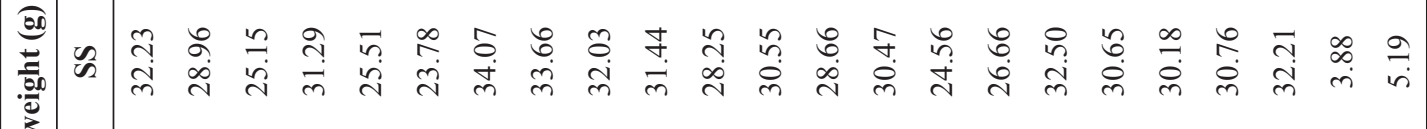
(3)

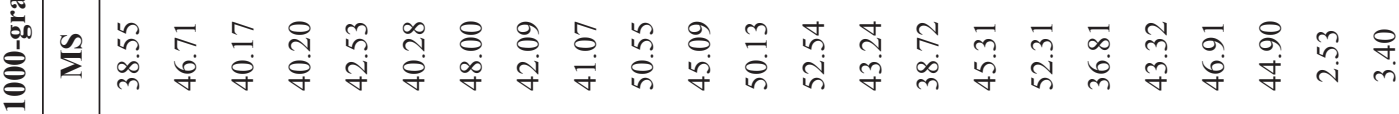

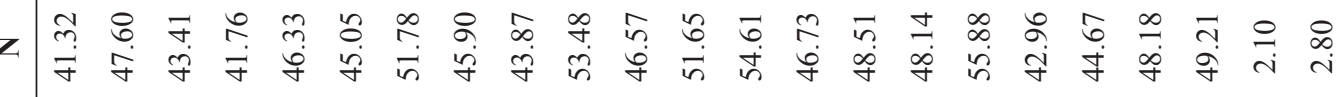
 匇 $\frac{\partial}{\frac{0}{2}}$

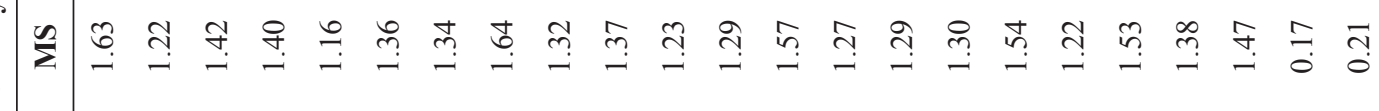

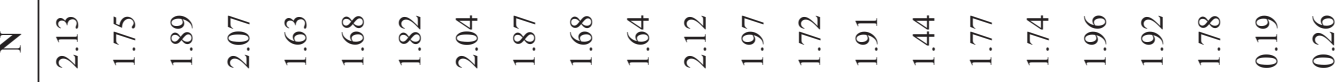




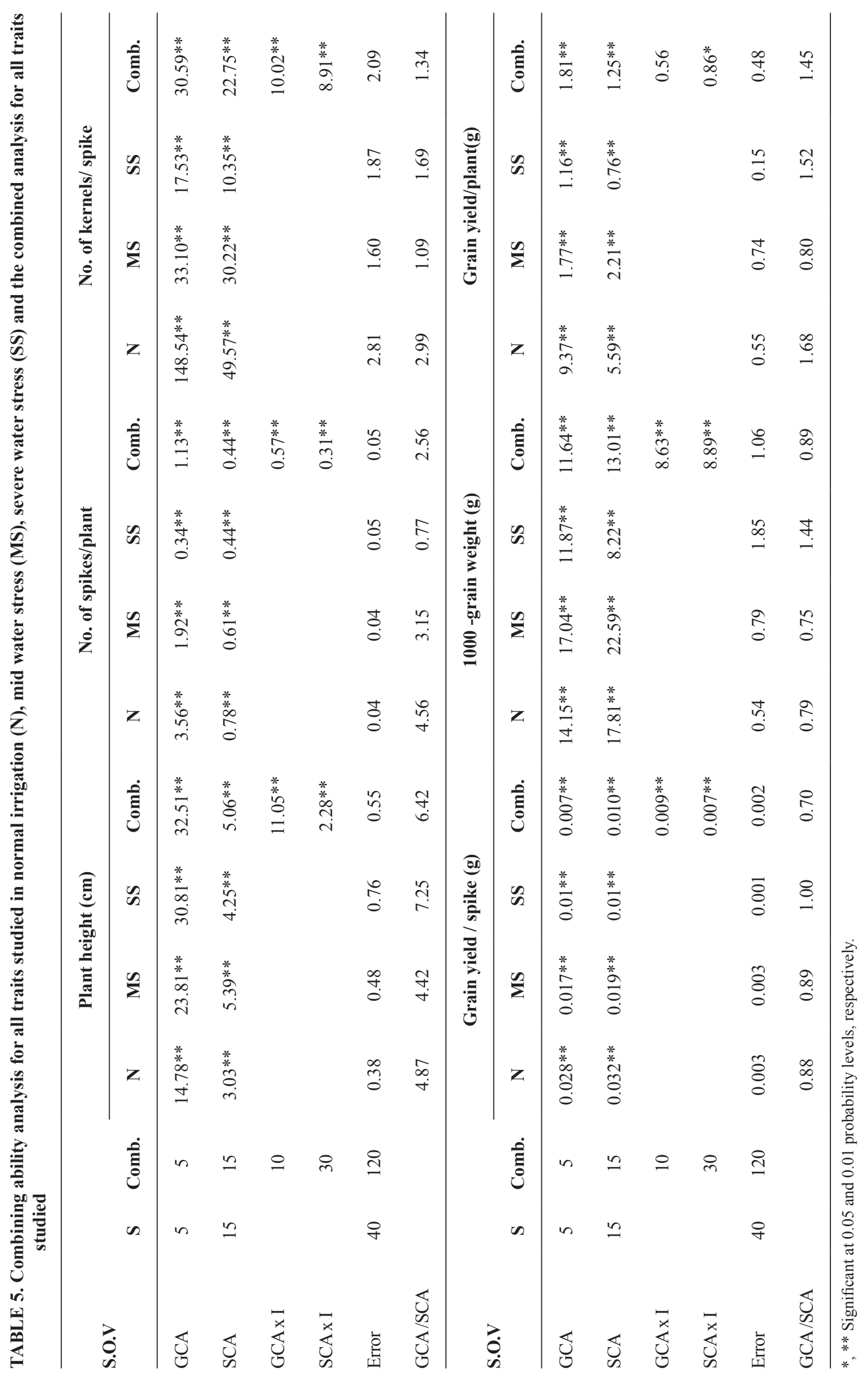

Egypt. J. Agron. 43, No. 2 (2021) 


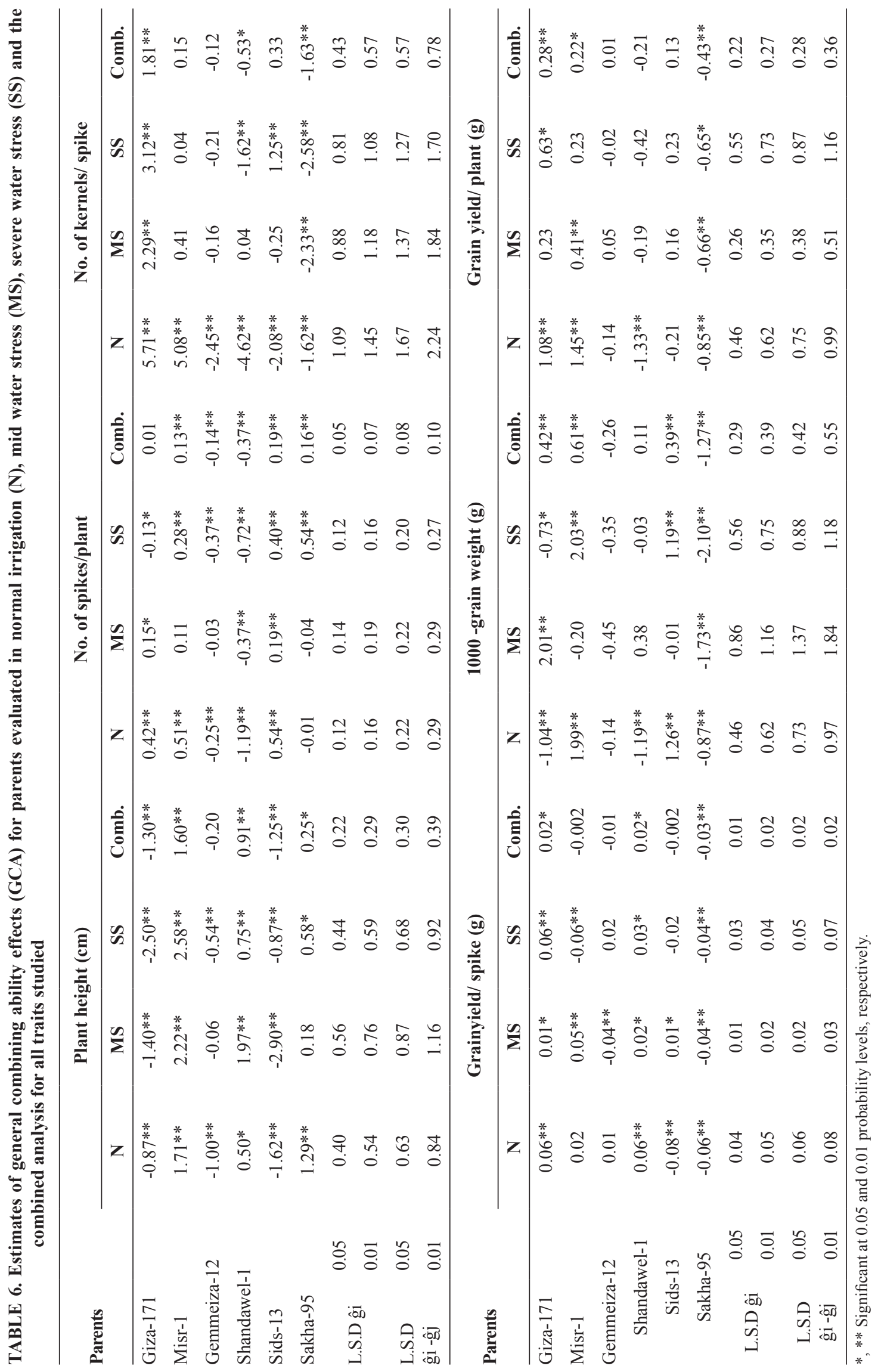

Egypt. J. Agron. 43, No. 2 (2021) 


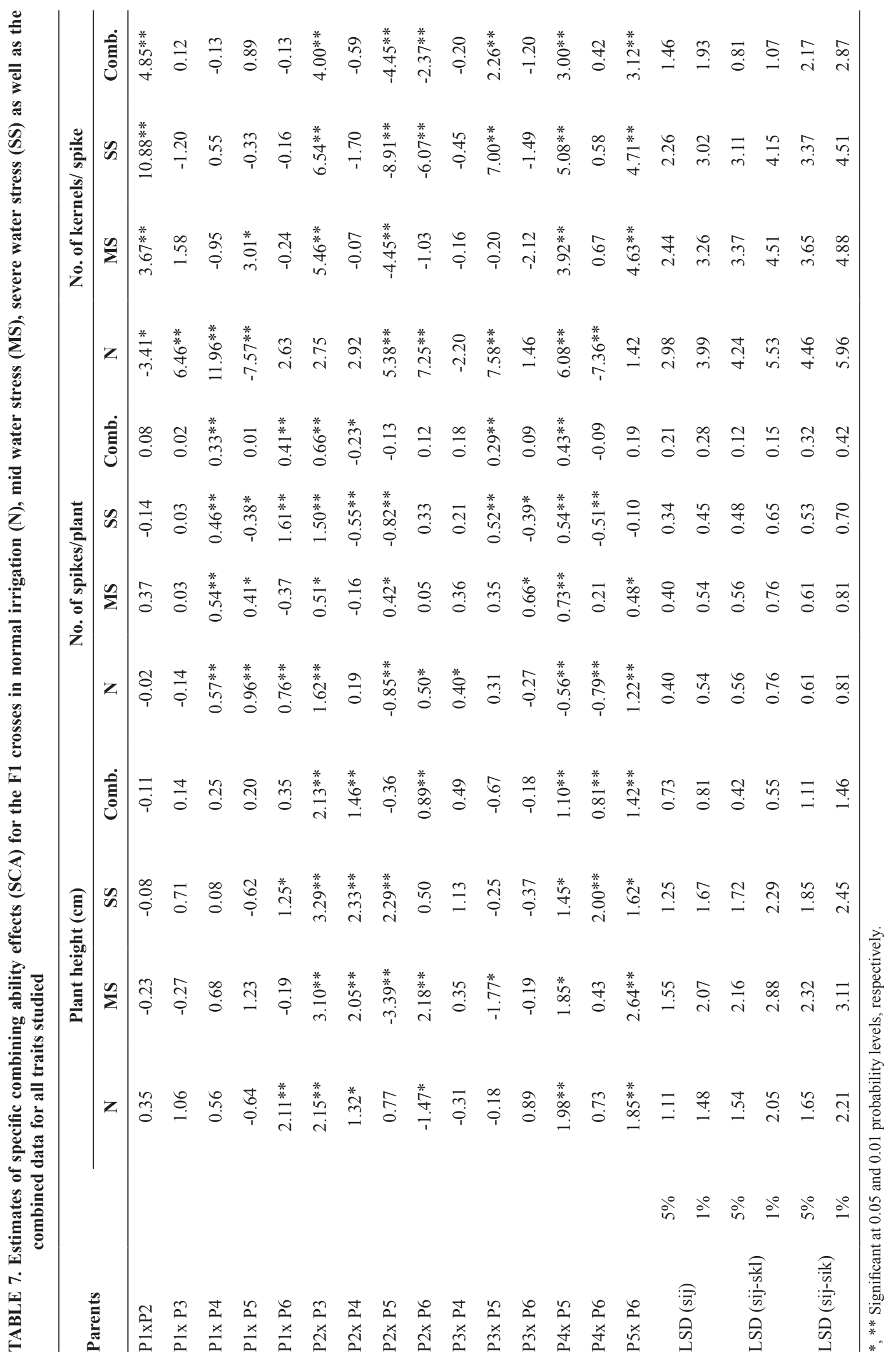




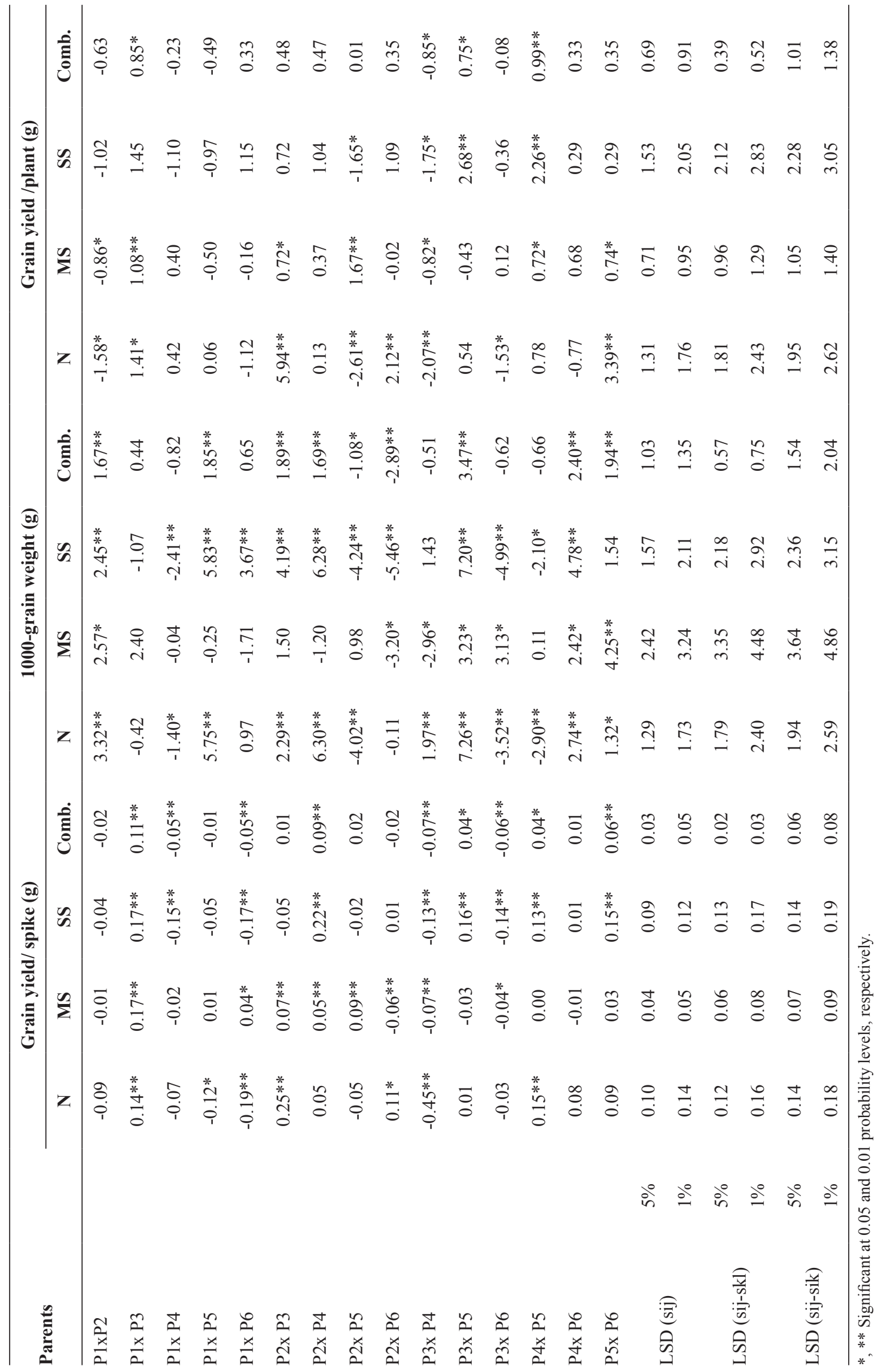

Egypt. J. Agron. 43, No. 2 (2021) 


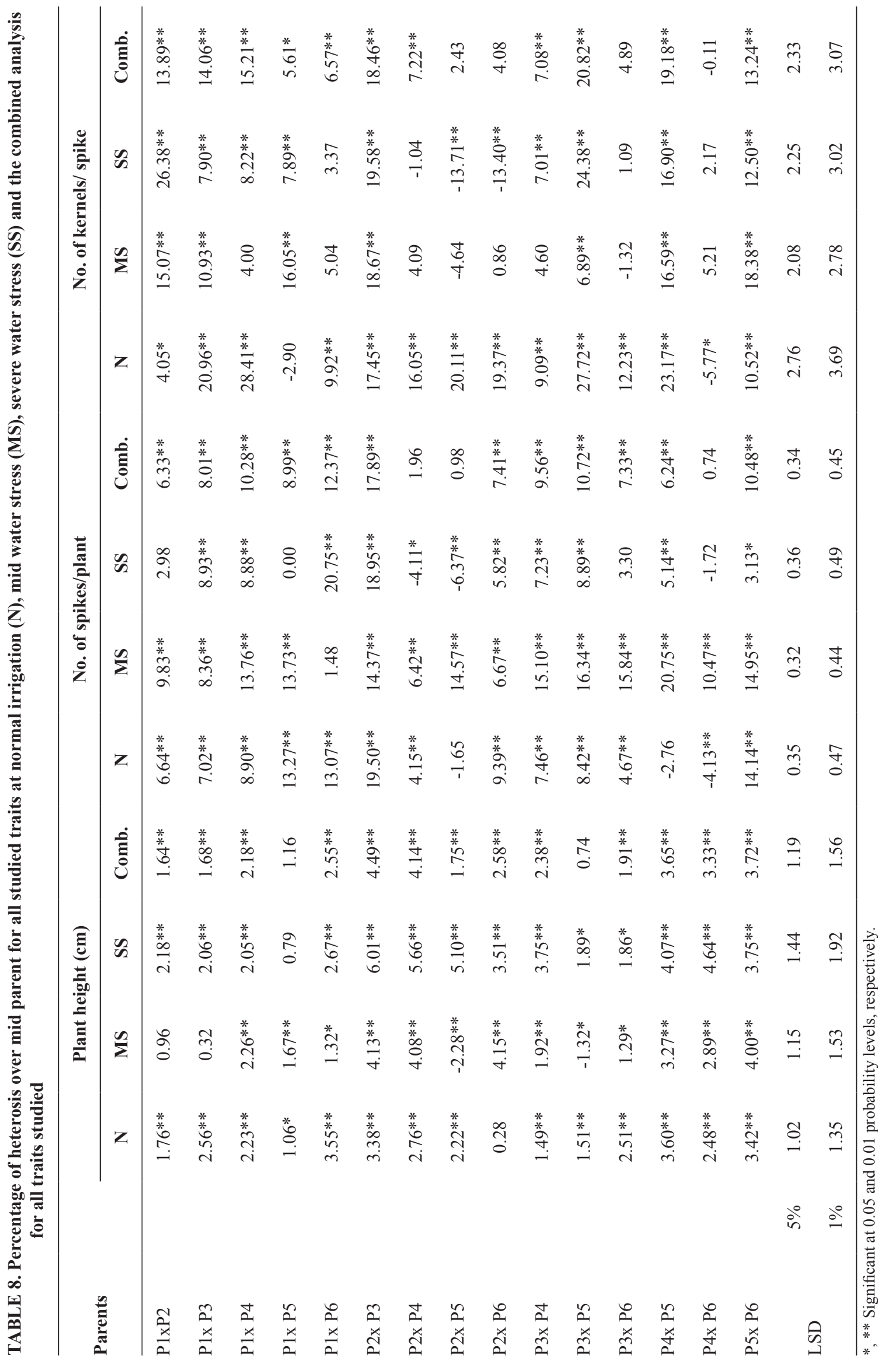

Egypt. J. Agron. 43, No. 2 (2021) 


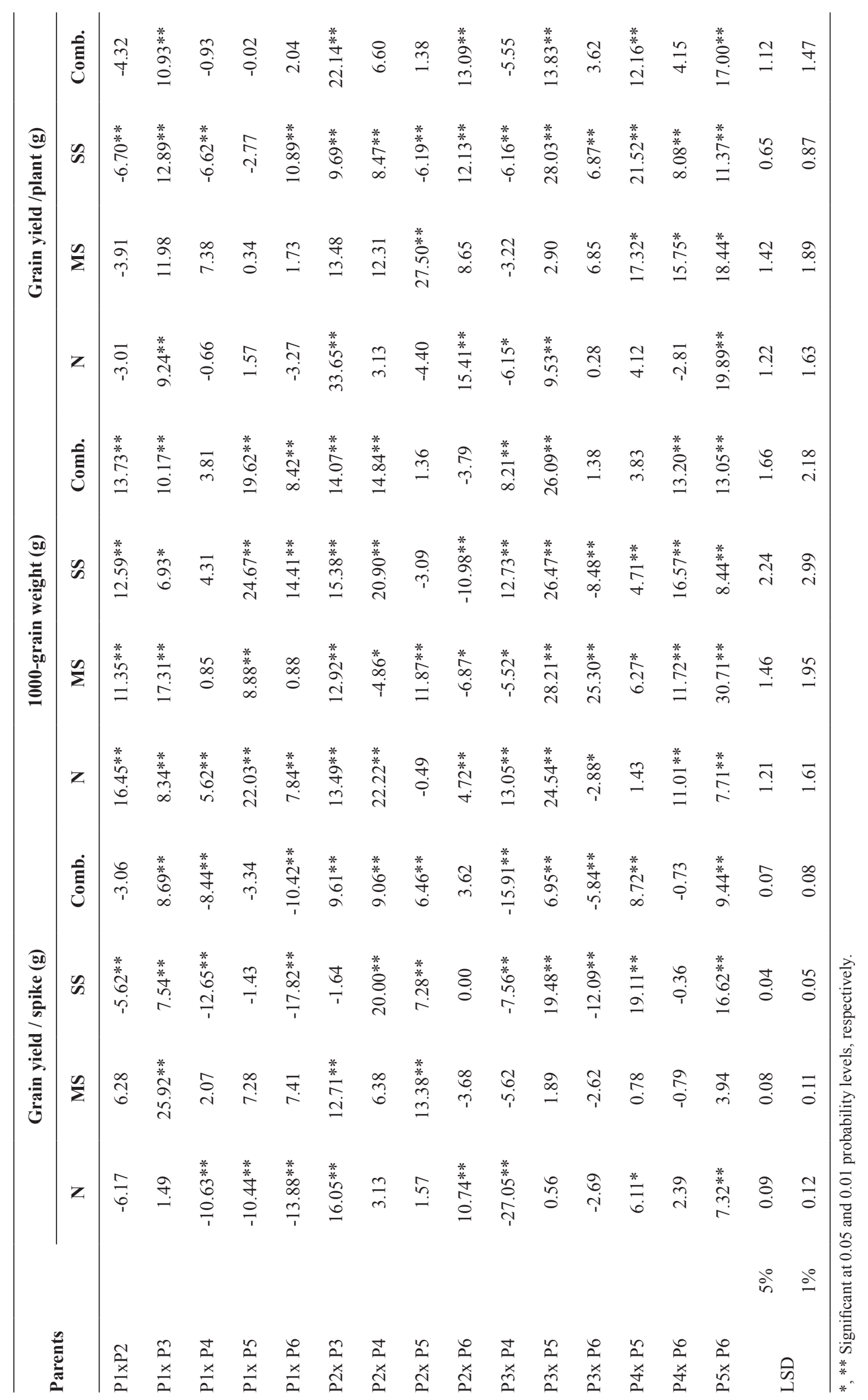

Egypt. J. Agron. 43, No. 2 (2021) 


\section{Conclusion}

Exposing plants to water stress adversely affect wheat genotypes productivity. Water stress management requires selection of suitable genotype that has drought tolerance. The parental varieties Giza-171 and Misr-1 were good combiners for number of kernels per spike, 1000-grain weight and grain yield per plant and the parental varieties Sids-13 was a good combiners for plant height (toward shortness), numbers per spikes per plant and grain yield per spike under drought stress conditions, indicating the performance of their general combining ability. Therefore, selection to improve such traits could be practiced either on mean performance or GCA effects basis with similar efficiency. On the other hand, the crosses P2 x P3, P2 x P5, P3 x P5, P4 x P5 and P5 x P6 were the significant desirable SCA effects for grain yield and its components under drought stress conditions. The best and highest positive heterosis were recorded in crosses P1 x P3, P2 x P3, P2 x P5, P3 x P5, P4 x P5, and P5 x P6. The hybrid combination could be used in breeding programs towards the development of pure lines wheat varieties for yield under drought conditions.

\section{Reference}

Ahmad, E., Kamar, A., Jaiswal, J.P. (2016) Identifying heterosis combinations for yield and quality traits in bread wheat (Triticum aestivumL.). Electronic Journal of Plant Breeding, 7(2), 352-361.

Abd El All, A.M., Ali, O.A.M. (2019) Application of jasmonic acid and lithovit to overcome adverse effects of drought stress in wheat. Journal of Plant Production, Mansoura University, 10(2), 205-215.

Ali, O.A.M., Mohammed, A.S.H. (2015) Performance evaluation of gated pipes technique for improving surface irrigation efficiency in maize hybrids. Agricultural Sciences, 6, 550-570.

Allen, R.G., Pereira, L.S., Raesand, D., Smith, M. (1998) Crop Evapotranspiration, Guidelines for Computing Crop Water Requirements. FAO Irrig. And Drain. Paper 59, Food and Agric. Orgn. of the United Nations, Rome, Italy. 300pp.

Bhumika, N.P., Desai, Rudranaik, S.A.V., Biradar, S.S., Arpitha, H.R., Kumar, A. (2018) Combining ability analysis for yield and spot blotch disease resistance in tetraploid wheat. International Journal of Current
Microbiology and Applied Sciences, 7(1), 18431847.

Chawla, H.S., Gupta, V.P. (1984) Index india- Agric. Calcutta Agricultural Society of India, 28(4), 261265.

Chowdhry, M.A., Rafiq, M., Alam, K. (1992). Genetic architecture of grain yield and certain other traits in bread wheat. Pakistan Journal of Agricultural Research, 13, 216-220.

Ding, Z., Kheir, A.M.S., Ali, M.G.M., Ali, O.A.M., Abdelaal, A.I.N., X.Lin, Zhou, Z., Wang, B., Liu, B., He, Z. (2020) The integrated effect of salinity, organic amendments, phosphorus fertilizers, and deficit irrigation on soil properties, phosphorus fractionation and wheat productivity. Scientific Reports, 10:2736; https://doi.org/10.1038/s41598020-59650.

Ding, Z., Kheir, A.M.S., Ali, O.A.M., Hafez, E.M., ElShamey, E.A., Zhou, Z., Wang, B., Lin, X., Ge, Y., Fahmy, A.E., Seleiman, M.F. (2021) A vermicompost and deep tillage system to improve saline-sodic soil quality and wheat productivity. Journal of Environmental Management, 277, 1 January 2021, 111388.

El- Hosary, A.A., El-Badawy, M.E.M., Mustafa, A.K., El-Shal, M.H. (2012) Evaluation of diallel wheat crosses under drought tolerance. Egyptian Journal of Plant Breeding, 16(1), 19-40.

El-Saadoown, A.W., El-Hosary, A.A., Sedhom, S.A., El-Badawy, M., El- Hosary, A.A.A. (2017) Genetic analysis of diallel crosses in wheat under stress and normal irrigation treatments. Egyptian Journal of Plant Breeding, 21(5), 279-292.

FAO (2019) Food and Agriculture Organization, http:// www.fao.org/faostat/en/\#data.

Farhat, W.Z.E., Mohamed, Eman N.M.M. (2018) Breeding for some agronomic and quality characters in bread wheat. Journal of Plant Production, Mansoura University, 9(3), 215-231.

Fonsecca, S., Patterson, F.L. (1968) Hybrid vigour in seven-parent diallel cross in common wheat (Triticum aestivum L.). Crop Science, 2, 85-88.

Gomaa, M.A., El-Banna, M.N.M., Gadalla, A.M., Kandil, E.E., Ibrahim, A.R.H. (2014) Heterosis, 
combining ability and drought susceptibility index in some crosses of bread wheat (Triticum aestivum L.) under water stress conditions. Middle East Journal of Agriculture Research, 3(2), 338-345.

Gomez, K.N., Gomez, A.A. (1984) "Statistical Procedures for Agricultural Research". John. Wiley and Sons. Inc., New York, $2^{\text {nd }}$ ed.

Gontia-Mishra, I., Sapre, S., Sharma, A., Tiwari, S. (2016) Amelioration of drought tolerance in wheat by the interaction of plant growth-promoting rhizobacteria. Plant Biology, 18, 992-1000.

Griffing, J.B. (1956) Concept of general and specific combining ability in relation to diallel crossing system. Australian Journal of Biological Sciences, 9, 463-493.

Hammad, S.A., Ali, O.A.M. (2014) Physiological and biochemical studies on drought tolerance of wheat plants by application of amino acids and yeast extract. Annals of Agricultural Sciences, 59(1), 133145 .

Khaled, M.A., Abd El-Daym, S.M. (2014) Combining ability analysis for grain yield and its attributes in bread wheat under stress and normal irrigation conditions. Journal of Plant Production, Mansoura University, 5(2), 255-266.

Khamssi, N.N. (2012) Selection criteria for improving grain yield of wheat under rain fed and irrigated condition. International Journal of Recent Scientific Research, 3(6), 489-495.

Khokhar, A.A., Nizamani, F.G., Rind, R.A., Nizamani, M.M., Khokhar, M.U., Shah, A., Nizamani, A.L., Rind, M. R. (2019) Combining ability estimates in $6 \times 6$ half diallel crosses of bread wheat (Triticum aestivum L.). Pure and Applied Biology, 8(3), 1980-1990.

Kumar, D., Panwar, I., Singh, V., Choudhary, R.R., Samita (2020) Heterosis studies using diallel analysis in bread wheat (Triticum aestivum L.).
International Journal of Chemical Studies, 8(4), 2353-2357.

Mehanna, H.M., Hussein, M.M., Nesreen, H.A. (2013) The relationship between water regimes and maize productivity under drip irrigation system: A statistical model. Journal of Applied Sciences Research, 9(6), 3735-3741.

Mwadzingeni, L., Shimelis, H., Tsilo, T.J. (2018) Combining ability and gene action controlling yield and yield components in bread wheat (Triticum aestivum L.) under drought-stressed and nonstressed conditions. Plant Breeding, 137, 502-513.

Noorka, I. R., Batool, A., Rauf, S., Silva, J.A.T., Ashraf, E. (2013) Estimation of heterosis in wheat (Triticum aestivum L.) under contrasting water regimes. International Journal of Plant Breeding, 7(1), 55-60.

Qabil, Naglaa (2017) Genetic analysis of yield and its attributes in wheat (Triticum aestivum L.) under normal irrigation and drought stress conditions. Egyptian Journal of Agronomy, 39(3), 337-356.

Saeed, M., Khalil, I.H., Nayab, D., Tanveer, M. (2016) Combining ability and heritability for yield traits in wheat (Triticum aestivum L.). Pakistan Journal of Agricultural Sciences, 53(3), 1-7.

Steel, R.G.D., Torrie, J.H. (1980) "Principles and Procedures of Statistics". Mc. Graw-Hill Book Company, New York, USA.

Swelam, D.A., Ali, A.M., Hassan, M.A., Salem, H.A. (2014) Selection criteria for improving wheat grain yield under normal irrigation and drought stress environments. Zagazig Journal of Agricultural Research, 41(4), 695-704.

Thomas, N., Marker, S., Lal, G.M., Dayal, A. (2017) Study of heterosis for grain yield and its components in wheat (Triticum aestivumL.) over normal and heat stress condition. Journal of Pharmacognosy and Phytochemistry, 6(4), 824-830. 


\section{تقدير القدرة علي التآلف وقوة الهجين لمحصول القمح ومكوناته تحت ظروف الإجهاد المائي \\ مروة محمد النحاس ، أسامة على محمد على إنى إنى

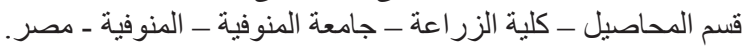

يعد الجفاف أحد المشاكل العالمية التى تتحكم في إنتاجية المحاصيل. لذا أجريت هذه الدر اسة بالمزر عة التجريبية

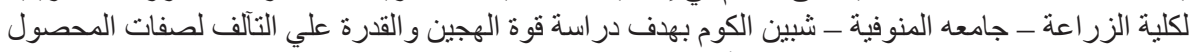

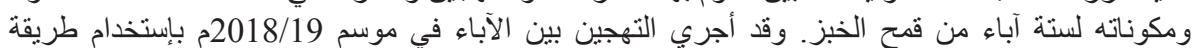

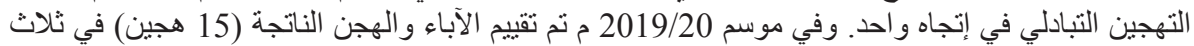

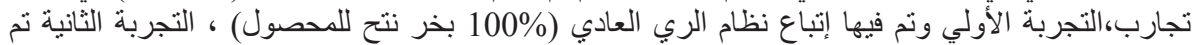

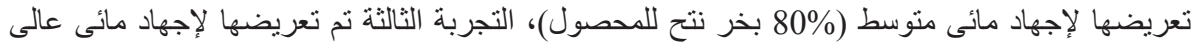

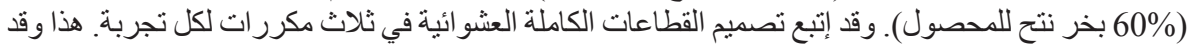

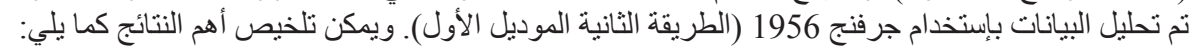
• كان التباين الر اجع للتر اكيب الور اثية (الأباء - الهجن - التفاعل بين الأباء و الهجن) معنويا لجميع صفات

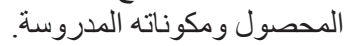
• أعطت الآباء P2 ، P2 أعلي القيم لصفات المحصول ومكوناتة تحت معاملات الري المختلفة و التحليل المشترك.

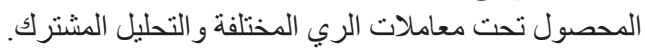

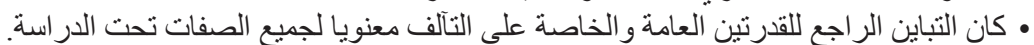

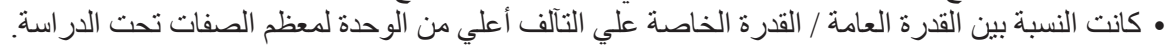

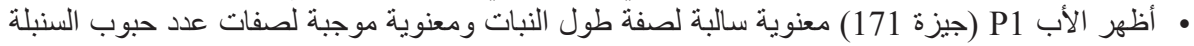
ومحصول السنبلة ومحصول النبات الفردى وذللك تحت معاملات الري المختلفة ولنة التحليل المشترك.

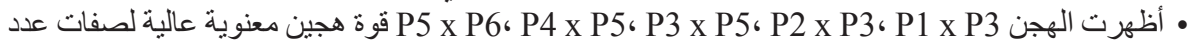

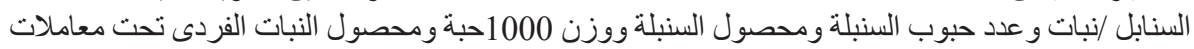
الري المختلفة والتحليل المشترك. 